\title{
FACTORS AFFECTING PNEUMONIA OCCURRENCE IN CHILDREN UNDER-FIVE IN NDUGA DISTRICT, PAPUA
}

\author{
Yulianda Yeimo'), Isna Qadrijati²), Bhisma Murti') \\ 1)Masters Program in Public Health, Universitas Sebelas Maret \\ ${ }^{2)}$ Faculty of Medicine, Universitas Sebelas Maret
}

\begin{abstract}
Background: The goverment of Nduga district, Papua, had reported that between 2012 to 2017 as many as 779 children under five had been diagnosed as pneumonia cases. Various factors had been hypothesized as the risk factors for pneumonia including poor health status, low family income, and unhealthy behaviour. In addition, Papua traditional homes "Honai" with high ambient indoor air pollution may increase the risk of pneumonia by damaging alveolar macrophages in the lungs. This study aimed to determine the factors affecting pneumonia occurrence in children under-five in Nduga, Papua.

Subjects and Method: This was an analytic observational study with a casecontrol design. The study was conducted in Yigi and Mbua Sub-districts, Nduga District, Papua, from December 2017 to February 2018. A sample of 184 children under-five consisting of 88 children with pneumonia (case) and 96 children without pneumonia (control), was selected for this study by fixed disease sampling. The independent variables were BCG immunization status, family income, indoor household air pollution, and environmental sanitation. The dependent variable was pneumonia. Data were collected by questionnaire and medical record. The data were analyzed by a multiple logistic regression.

Results: The risk of pneumonia in children under-five increased by absence of BCG immunization $(\mathrm{OR}=6.15 ; 95 \% \mathrm{CI}=2.78$ to $13.61 ; \mathrm{p}<0.001)$, poor indoor household air pollution $(\mathrm{OR}=5.68 ; 95 \% \mathrm{CI}=2.63$ to 12.26 ; $\mathrm{p}<0.001)$, and poor sanitation $(\mathrm{OR}=5.06$; $95 \% \mathrm{CI}=2.16$ to $11.83 ; \mathrm{p}<0.001)$. The risk of pneumonia in children under-five decreased by higher family income $(\mathrm{OR}=0.30 ; 95 \% \mathrm{CI}=0.13$ to $0.70 ; \mathrm{p}=0.005$ ).

Conclusion: Pneumonia in children under five increases by indoor household air pollution, poor sanitation, absence BCG immunization, and lower family income.
\end{abstract}

Keywords: pneumonia, indoor pollution, sanitation, BCG immunization, family income

\section{Correspondence:}

Yulianda Yeimo. Nduga District Health Office, Jl. Kesehatan, Kabupaten Nduga, Papua. Email: yulianda.yeimo@gmail.com. Mobile: 082198811311. 